\title{
Measuring mercury concentration
}

\section{Citation}

Grandjean, Philippe, and Poul J. Jørgensen. 2005. "Measuring mercury concentration." Epidemiology 16.

\section{Permanent link}

http://nrs.harvard.edu/urn-3:HUL.InstRepos:34786614

\section{Terms of Use}

This article was downloaded from Harvard University's DASH repository, and is made available under the terms and conditions applicable to Other Posted Material, as set forth at http:// nrs.harvard.edu/urn-3:HUL.InstRepos:dash.current.terms-of-use\#LAA

\section{Share Your Story}

The Harvard community has made this article openly available.

Please share how this access benefits you. Submit a story.

Accessibility 
To the Editor,

Daniels et al. ${ }^{1}$ studied the association between maternal fish intake and neurobehavioral development in the child. In a convenience subsample of 1054 selected from a larger number of births, the authors measured the mercury concentration in umbilical cord tissue. The authors expressed the mercury level on a wet-weight basis. Although fish-eating mothers had an increased cord-mercury concentration, Figure 1 suggests that, among fisheaters, the mercury concentration was independent of the frequency of fish intake. The paper includes only limited analytical quality information, except that subsequent analyses of other cords from the study were said to show lower results by another analytical method. We are therefore surprised that the authors conclude from their findings that maternal fish intake is a validated surrogate for mercury exposure. In our view, the cord mercury concentration is a possible candidate as methylmercury exposure biomarker, but it needs proper validation.

Previous studies using the cord mercury concentration have expressed the result in terms of dry weight. ${ }^{2,3}$ This choice is meaningful, because the amount of watery Wharton's jelly varies considerably and decreases with the duration of gestation. ${ }^{4}$ Our experience agrees with the statement by Daniels et al. ${ }^{1}$ that the water content of the cord is usually about $85-90 \%$. However, we find that the water content may vary from $62 \%$ to $95 \%$ in different cords. In 10 split samples, the wet-weight-based mercury concentration showed an average CV of $17 \%$, i.e., much more than can be attributed to analytical variability. In contrast, mercury concentrations in split freeze-dried samples showed an average CV of $4 \%$, i.e., similar to the normal laboratory error. ${ }^{2}$ The dry-weight based mercury concentration would therefore seem to be a more precise parameter. An imprecise exposure assessment will tend to underestimate the true effect of the exposure and may also complicate confounder adjustment. ${ }^{5}$

As noted by the authors, maternal assessment of the child's development up to 18 months of age is unlikely to be a sensitive measure of methylmercury neurotoxicity. More sophisticated testing at school age would be required. If such follow-up is conducted in this important cohort, we recommend that exposure assessment leave out the water and focus on the dry mercury concentrations.

\section{REFERENCES}

1. Daniels, JL, Longnecker MP, Rowland AS, Golding J, The ALSPAC Study Team. Fish intake during pregnancy and early cognitive development of offspring. Epidemiology 2004; 15: 394-402.

2. Dalgård C, Grandjean P, Jørgensen PJ, Weihe P. Mercury in the umbilical cord: Implications for risk assessment for Minamata disease. Environ Health Perspect 1994; 102 : 548-50.

3. Akagi H, Grandjean P, Takizawa Y, Weihe P. Methylmercury dose estimation from umbilical cord concentrations in patients with Minamata disease. Environ Res 1998; 77: 98103.

4. Sloper KS, Brown RS, Baum JD. The water content of the human umbilical cord. Early Hum Dev 1979; 3: 205-10.

5. Budtz-Jørgensen E, Keiding N, Grandjean P, Weihe P, White RF. Consequences of exposure measurement error for confounder identification in environmental epidemiology. Stat Med 2003; 22: 3089-100. 